\title{
FAKTOR-FAKTOR YANG BERHUBUNGAN DENGAN KEJADIAN RUPTUR PERENIUM PADA PERSALINAN NORMAL DI BPM Hj.ROSDIANA, S.SiT KECAMATAN JEUNIB KABUPATEN BIREUEN
}

\author{
The Factors Related To The Occurrence Of Perineal Rupture In Normal Delivery Mothers \\ At BPM Hj. Rosdiana, S.SiT District Of Jeunieb \\ Bireuen Regency
}

Ferinawati $^{* 1}$, Marjuani ${ }^{2}$

1. Dosen Akbid Munawarah, Jl. Sultan Iskandar Muda No. 18 Kota Juang, Bireuen 24251, Indonesia

2. Mahasiswa Akbid Munawarah, Jl. Sultan Iskandar Muda No. 18 Kota Juang, Bireuen 24251, Indonesia

*Korespondensi Penulis : ferinabireuen88@gmail.com ${ }^{* 1}$, marjuanim910gmail.com ${ }^{2}$

\begin{abstract}
Abstrak
Latar Belakang : World Health Organization (WHO) pada tahun 2015 memperkirakan di seluruh dunia setiap tahunnya lebih dari 585.000 ibu meninggal akibat komplikasi kehamilan dan persalinan. Di Asia ruptur perineum dalam masyarakat, 50\% dari kejadian ruptur perineum di dunia. Tujuan : Untuk mengetahui Faktor Yang Berhubungan Dengan Terjadinya Ruptur Perineum Pada Ibu Persalinan Normal di BPM Hj. Rosdiana, S.SiT Kecamatan Jeunieb Kabupaten Bireuen. Metode : Penelitian ini menggunakan survei analitik dengan pendekatan cross sectional. Penelitian dilaksanakan di BPM Hj. Rosdiana, S.SiT Kecamatan Jeunib Kabupaten Bireuen. Populasi dalam penelitian ini seluruh ibu nifas berusia 0-44 hari yang melakukan persalinan normal di BPM Hj. Rosdiana, S.SiT sebanyak 36 orang dengan teknik pengambilan sampel total population yaitu seluruh populasi dijadikan sampel. Teknik pengumpulan data menggunakan data primer dan sekunder dan diolah ke dalam analisis univariat dan bivariat. Hasil : Berdasarkan hasil penelitian dengan uji statistik chi square yang telah dilakukan pada bulan agustus 2020 menunjukkan ada hubungan antara berat badan bayi lahir dengan kejadian ruptur perineum (nilai $\mathrm{p}$ value 0,000 ), tidak ada hubungan antara paritas dengan kejadian ruptur perineum (nilai p value 0,377 ) dan tidak ada hubungan antara jarak kelahiran dengan kejadian ruptur perineum (nilai p value 0,289). Kesimpulan : Ada hubungan yang signifikan antara berat badan bayi lahir dengan kejadian ruptur perineum, Tidak ada hubungan yang signifikan antara paritas dan jarak kelahirak dengan kejadian ruptur di BPM Hj. Rosdiana, S.SiT Kecamatan Jeunib Kabupaten Bireuen. Diharapkan kepada BPM Hj.Rosdiana, S.SiT agar dapat meningkatkan kualitas pelayanan kesehatan, bidan juga diharapkan dapat bekerja sama dengan ibu dalam proses persalinan dan lebih memperhatikan faktor-faktor risiko yang dapat mempengaruhi kejadian ruptur perineuem sehingga kejadian ruptur perineum dapat dicegah.
\end{abstract}

Kata kunci

: Berat Badan Bayi Lahir, Paritas, Jarak Kelahiran, Ruptur Perenium

\begin{abstract}
Background: The World Health Organization (WHO) in 2015 estimated that worldwide more than 585,000 women die from complications from pregnancy and childbirth every year. In Asia perineal rupture in society, 50\% of the incidence of perineal rupture in the world. Objective: The purpose of this study was to determine factors related to the occurrence of
\end{abstract}


Journal of Healthcare Technology and Medicine Vol. 6 No. 2 Oktober 2020

Universitas Ubudiyah Indonesia

e-ISSN : 2615-109X

perineal rupture in normal delivery mothers at BPM Hj. Rosdiana, S.SiT District of Jeunieb Bireuen Regency. Method: This study used an analytic survey with a cross sectional approach. The research was conducted at BPM Hj. Rosdiana, S.SiT, Jeunib District, Bireuen Regency. The population in this study were all postpartum mothers aged 0-44 days who had a normal delivery at BPM Hj. Rosdiana, S.SiT as many as 36 people with a total population sampling technique, namely the entire population was sampled. Data collection techniques used primary and secondary data and were processed into univariate and bivariate analyzes. Results: Based on the results of research with the chi square statistical test conducted in August 2020, it shows that there is a relationship between birth weight and the incidence of perineal rupture ( $p$ value 0.000), there is no relationship between parity and the incidence of perineal rupture ( $p$ value 0.377) and there was no relationship between birth spacing and the incidence of perineal rupture ( $p$ value 0.289).Conclusion: There is a significant relationship between birth weight and the incidence of perineal rupture. There is no significant relationship between parity and birth distance with the incidence of rupture in BPM Hj. Rosdiana, S.SiT, Jeunib District, Bireuen Regency. It is hoped that BPM Hj.Rosdiana, S.SiT can improve the quality of health services, midwives are also expected to cooperate with mothers in the delivery process and pay more attention to risk factors that can affect the incidence of perineum rupture so that the incidence of perineal rupture can be prevented.

Keywords $\quad$ : Birth weight, parity, birth distance, perineal rupture

\section{PENDAHULUAN}

Angka kematian ibu (AKI) merupakan salah satu indikator penting dalam menilai tingkat derajat kesehatan masyarakat di suatu negara. Pada tahun 2015 World Health Organization (WHO) memperkirakan di seluruh dunia setiap tahunnya lebih dari $585.000 \mathrm{ibu}$ meninggal akibat komplikasi kehamilan dan persalinan (Wijayanti, 2019).

Adapun Target global SDGs (Suitainable Development Goals) adalah menurunkan Angka Kematian Ibu (AKI) menjadi 70 per $100.000 \mathrm{KH}$. Mengacu dari kondisi saat ini, potensi untuk mencapai target SDGs untuk menurunkan AKI adalah off track, artinya diperlukan kerja keras dan sungguh sungguh untuk mencapainya. Pada kenyataannya, Angka Kematian Ibu turun dari 4.999 tahun 2015 menjadi 4912 di tahun 2016 dan di tahun 2017 sebanyak 1712 kasus. Penyebab kematian ibu adalah komplikasi kehamilan seperti anemia, hipertensi. Gangguan persalinan langsung misalnya perdarahan sebesar 28\%, infeksi sebesar $11 \%$, eklamsia sebesar 24\%, dan partus macet (lama) sebesar 5\% (Kemkes RI, 2017). Penyebab tingginya AKI adalah perdarahan dan penyebab terjadinya perdarahan adalah atonia uteri, ruptur perineum, dan sisa plasenta (Ariani, 2018).

Persalinan adalah suatu proses pengeluaran hasil konsepsi berupa janin dan plasenta dari rahim melalui jalan lahir. Pada periode pasca persalinan dapat terjadi berbagai macam komplikasi seperti perdarahan karena atonia uteri, retensio plasenta dan ruptur perenium. 
Journal of Healthcare Technology and Medicine Vol. 6 No. 2 Oktober 2020

Universitas Ubudiyah Indonesia

e-ISSN : 2615-109X

Ruptur perenium adalah perlukaan jalan lahir yang terjadi pada saat kelahiran bayi baik menggunakan alat ataupun tidak menggunakan alat. Ruptur perenium umumnya terjadi di garis tengah dan bisa menjadi luas apabila kepala janin lahir terlalu cepat (Yugistyowati, 2015).

Di Negara berkembang penyebab utama kematian ibu adalah faktor obstetri langsung, yaitu perdarahan postpartum, infeksi dan eklamsia. Ruptur perineum dapat menyebabkan perdarahan postpartum. Perdarahan postpartum merupakan salah satu masalah penting karena berhubungan dengan kesehatan ibu yang dapat menyebabkan kematian. Walaupun angka kematian maternal telah menurun dari tahun ke tahun dengan adanya pemeriksaan dan perawatan kehamilan, persalinan dirumah sakit serta adanya fasilitas transfusi darah, namun perdarahan masih tetap merupakan faktor utama dalam kematian ibu (Anggraini, 2018).

Ruptur perenium adalah robeknya perineum pada saat janin lahir. Robekan ini sifatnya traumatik karena perineum tidak kuat menahan regangan pada saat janin lewat. Dampak dari terjadinya ruptur perineum pada ibu dapat mengakibatkan terjadinya infeksi pada luka jahitan di mana dapat merambat pada saluran kandung kemih ataupun pada jalan lahir yang dapat berakibat pada munculnya komplikasi infeksi kandung kemih maupun infeksi pada jalan lahir. Ruptur perineum juga dapat mengakibatkan perdarahan karena terbukanya pembuluh darah yang tidak menutup sempurna sehingga perdarahan terjadi terus menerus. Penanganan komplikasi yang lambat dapat menyebabkan terjadinya kematian pada ibu post partum mengingat kondisi fisik ibu post partum masih lemah (Sumaryani, 2015).

Di Indonesia angka kejadian ruptur perenium mencapai $30 \%$ dari penyebab perdarahan pada saat persalinan, kejadian ruptur perenium penyebab pendarahan setelah atonia uteri, dan menurut hasil survey sensus penduduk pada tahun 2010 AKI di provinsi Indonesia didapatkan bahwa AKI di Jawa Tengah tahun 2012 yaitu 117 per 100.000 kelahiran hidup ada sedikit peningkatan AKI dibandingkan tahun 2011 yaitu 116 per 100.000 kelahiran hidup. Penyebab langsung kematian ibu di Indonesia terkait kehamilan dan persalinan adalah perdarahan, eklampsi, infeksi, partus lama, dan abortus $5 \%$.

Robekan perineum dipengaruhi oleh beberapa faktor yaitu faktor maternal, faktor janin dan faktor penolong. Faktor maternal meliputi partus presipitatus yang tidak dikendalikan dan tidak ditolong. Pasien tidak mampu berhenti mengejan, partus diselesaikan secara tergesa-gesa dengan dorongan fundus yang berlebihan, edema dan kerapuhan pada perineum, varikositasvulva melemahkan jaringan perineum, arcus pubis sempit dengan pintu bawah panggul yang sempit pula sehingga menekan kepala bayi kearah posterior, perluasan 
Journal of Healthcare Technology and Medicine Vol. 6 No. 2 Oktober 2020

Universitas Ubudiyah Indonesia

e-ISSN : 2615-109X

episiotomi. Faktor janin antara lain bayi yang besar, posisi kepala yang abnormal (misalnya presentasi muka), kelahiran bokong, ektraksi forcepsyang sukardistosia bahu, anomaly congenital, seperti hydrosepalus. Faktor penolong yaitu posisi meneran pada posisi persalinan (Anggraini, 2017).

Berat badan bayi dapat mempengaruhi proses persalinan kala II. Berat badan bayi lahir umumnya antara 2500-4000 gram. Semakin besar bayi yang dilahirkan akan meningkatkan resiko terjadinya ruptur perineum. Sedangkan dilihat dari status paritas umumnya ruptur perineum terjadi pada primipara, tetapi tidak jarang juga terjadi pada multipara. Penyebab yang biasa terjadi pada ibu adalah partus presipitatus, mengejan terlalu kuat, edema dan kerapuhan pada perineum, kelenturan jalan lahir, persalinan dengan tindakan (Pemiliana,2019)

Pengaturan jarak kehamilan yang ideal juga akan berdampak terhadap kesehatan ibu. Kesehatan reproduksi ibu akan mengalami pemulihan yang optimal jika jarak kehamilan tidak terlalu dekat. Akan tetapi jika jarak terlalu jauh atau terlalu lama juga kurang bagus bagi kesehatan ibu. Hal ini dapat terlihat dari hasil penelitian bahwa ibu dengan jarak anak >5 tahun lebih banyak mengalami ruptur perenium. Hal itu terjadi karena perenium sudah kaku dan otot tidak elastis seperti pada kehamilan kedua atau ketiga (Sigalingging, 2018).

Berdasarkan profil kesehatan Aceh Tahun 2017, diketahui jumlah kematian ibu yang dilaporkan sebanyak 141 kasus dan lahir hidup 101.296 jiwa, maka rasio angka kematian ibu di Aceh kembali menunjukkan penurunan menjadi 139 per 100.000 lahir hidup. Tingginya AKI disebabkan pada proses persalinan yang diakibatkan oleh perdarahan $21 \%$, infeksi $15 \%$, eklamsia 5\%, partus macet $3 \%$ (Dinkes Aceh, 2017).

Berdasarkan data yang diperoleh dari Dinas Kesehatan Kabupaten Bireuen dari bulan Januari sampai Desember 2019, jumlah ibu bersalin sebanyak 8.573 jiwa (89,7\%). Dari total tersebut, 8.570 jiwa mendapatkan pelayanan kesehatan dari tenaga medis (Dinkes Bireuen, 2019).

Hasil survey awal yang peneliti lakukan di BPM Hj. Rosdiana S.SiT jumlah ibu bersalin yang terdata sebanyak 52 ibu bersalin. Menurut keterangan dari Bidan Rosdiana dari 10 ibu bersalin, 7 dari mereka mengatakan mengalami robekan jalan lahir saat persalinan, 3 orang lainnya tidak mengalami robekan jalan lahir. Dari 7 ibu yang mengalami ruptur perenium, terdapat 5 ibu yang melahirkan bayi dengan berat badan > 3000 gram, 2 ibu melahirkan dengan paritas primipara. Sedangkan ibu bersalin yang tidak mengalami ruptur adalah ibu yang melahirkan bayi dengan berat badan bayi lahir rendah. 
Journal of Healthcare Technology and Medicine Vol. 6 No. 2 Oktober 2020

Universitas Ubudiyah Indonesia

e-ISSN : 2615-109X

Berdasarkan latar belakang diatas, maka peneliti tertarik untuk meneliti tentang "Faktor-faktor yang berhubungan dengan kejadian ruptur perineum di BPM $\mathrm{Hj}$. Rosdiana S.SiT Kecamatan Jeunieb Kabupaten Bireuen".

\section{METODE PENELITIAN}

Jenis penelitian ini adalah penelitian analitik. Desain penelitian ini menggunakan desain pendekatan Cross Sectional. Lokasi penelitian di lakukan di BPM Hj. Rosdiana, S.SiT Kecamatan Jeunib Kabupaten Bireuen Tahun 2020. Waktu penelitian dimulai dari bulan Agustus 2020. Populasi dalam penelitian ini adalah seluruh ibu nifas yang melakukan persalinan normal dengan ruptur perenium yang terdapat di BPM Hj. Rosdiana, S.SiT Kecamatan Jeunib Kabupaten Bireuen. Tehnik pengambilan sampel menggunakan tehnik total populasi dengan cara melakukan kunjungan rumah terhadap ibu nifas berusia 0-44 hari yang melakukan persalinan normal di BPM Hj. Rosdiana, S.SiT Kecamatan Jeunieb Kabupaten Bireuen sebanyak 36 responden. Data dianalisis secara univariat dan bivariat dengan uji chi-square.

\section{HASIL PENELITIAN}

Analisis Univariat digunakan untuk mengetahui faktor-faktor yang berhubungan dengan kejadian ruptur perenium.

Tabel 1. Distribusi Frekuensi Kejadian Ruptur Perenium di BPM Hj. Rosdiana, S.SiT Kecamatan Jeunib Kabupaten Bireuen Tahun 2020

\begin{tabular}{ccc}
\hline Analisis Univariat & f & Jumlah \\
\cline { 2 - 3 } Kejadian Ruptur Perenium & & $\mathbf{( \% )}$ \\
Mengalami & 29 & 81 \\
Tidak Mengalami & 7 & 19 \\
\hline Berat Bada Bayi Lahir & 3 & 8 \\
$<2500$ & 23 & 64 \\
2500-4000 & 10 & 28 \\
$>4000$ & & \\
Paritas & 6 & 17 \\
Primipara & 27 & 75 \\
Multipara & 3 & 8 \\
Grandemultipara & 6 & 17 \\
Jarak Kelahiran & 28 & 77 \\
Anak Pertama & &
\end{tabular}




\begin{tabular}{ccc}
$<2$ Tahun & 2 & 6 \\
\hline Jumlah & $\mathbf{3 6}$ & $\mathbf{1 0 0}$ \\
\hline
\end{tabular}

Berdasarkan tabel diatas, dapat dilihat mayoritas mayoritas mengalami ruptur perenium yaitu sebanyak 29 responden (81\%). mayoritas responden memiliki berat badan bayi lahir 2500-4000 gram yaitu sebanyak 23 responden (64\%). mayoritas responden memiliki paritas multipara yaitu sebanyak 27 responden (75\%). mayoritas responden memiliki jarak kelahiran $\geq 2$ Tahun yaitu sebanyak 28 responden (77\%).

Analisis Bivariat digunakan untuk mengetahui hubungan antara variabel independen terhadap variabel dependen dengan menggunakan chi-square pada tingkat kemaknaan 95\% atau nilai $(\alpha=0,05)$. Bila menunjukan nilai $\mathrm{p} \leq 0,05$ artinya ada hubungan bermakna atau signifikan.

Tabel 2. Uji Silang Uji Silang Kejadian Ruptur Perenium dengan Berat Badan Bayi Lahir, Paritas dan Jarak Kelahiran di BPM Hj. Rosdiana, S.SiT Kecamatan Jeunib Kabupaten Bireuen Tahun 2020

\begin{tabular}{|c|c|c|c|c|c|c|c|}
\hline \multirow{3}{*}{ Analisis Bivariat } & \multicolumn{4}{|c|}{ Ruptur Perenium } & & & \multirow{3}{*}{ P-Value } \\
\hline & \multicolumn{2}{|c|}{ Mengalami } & \multicolumn{2}{|c|}{$\begin{array}{c}\text { Tidak } \\
\text { Mengalami }\end{array}$} & \multicolumn{2}{|c|}{$\sum$} & \\
\hline & Jlh & $\%$ & Jlh & $\%$ & Jlh & $\%$ & \\
\hline \multicolumn{8}{|c|}{ Berat Badan Bayi Lahir } \\
\hline$<2500$ & 0 & 0 & 3 & 8 & 3 & 8 & \multirow{2}{*}{0,000} \\
\hline $2500-4000$ & 22 & 61 & 1 & 3 & 23 & 64 & \\
\hline$>4000$ & 7 & 19 & 7 & 8 & 10 & 28 & \\
\hline \multicolumn{8}{|l|}{ Paritas } \\
\hline Primipara & 6 & 17 & 0 & 0 & 6 & 17 & 0,377 \\
\hline Multipara & 21 & 58 & 6 & 16 & 27 & 75 & \\
\hline Grandemultipara & 2 & 6 & 1 & 3 & 3 & 8 & \\
\hline \multicolumn{8}{|l|}{ Jarak Kelahiran } \\
\hline Anak Pertama & 6 & 17 & 0 & 0 & 6 & 17 & 0,289 \\
\hline$\geq 2$ Tahun & 21 & 58 & 7 & 19 & 28 & 77 & \\
\hline$<2$ Tahun & 2 & 6 & 0 & 0 & 2 & 6 & \\
\hline Jumlah & 29 & 81 & 7 & 19 & 36 & 100 & \\
\hline
\end{tabular}

Berdasarkan uji silang diatas, dari 36 responden mayoritas responden yang mengalami ruptur perenium merupakan ibu yang melahirka bayi 2500-4000 gram yaitu sebanyak 22 responden (61\%), >4000 sebanyak 7 responden (19\%) dan <2500 sebanyak $0(0 \%)$, mayoritas responden yang mengalami ruptur perenium adalah ibu yang memiliki paritas multipara yaitu sebanyak 21 responden (58\%), primipara sebanyak 6 responden (17\%), dan grandemultipara 
Journal of Healthcare Technology and Medicine Vol. 6 No. 2 Oktober 2020

Universitas Ubudiyah Indonesia

e-ISSN : 2615-109X

sebanyak 2 responden (6\%), mayoritas responden yang mengalami ruptur perenium adalah ibu yang memiliki jarak kelahiran $\geq 2$ tahun yaitu sebanyak 21 responden (58\%), anak pertama sebanyak 6 responden (17\%) dan $<2$ tahun sebanyak 2 responden $(6 \%)$.

Hasil uji statistik chi square dengan tingkat kepercayaan 95\% $(\alpha=0,05)$ hasil perhitungan berat badan bayi lahir menunjukkan nilai $\mathrm{p}(0,000)<\mathrm{p}$ value $(0,05)$ berarti ada hubungan antara kejadian ruptur perenium dengan berat badan bayi lahir, hasil perhitungan paritas menunjukkan nilai $\mathrm{p}(0,377)>\mathrm{p}$ value $(0,05)$ berarti tidak ada hubungan antara kejadian ruptur perenium dengan paritas, hasil perhitungan jarak kelahiran menunjukkan nilai $\mathrm{p}(0,289)>\mathrm{p}$ value $(0,05)$ berarti tidak ada hubungan antara jarak kelahiran dengan kejadian ruptur perenium.

\section{PEMBAHASAN}

\section{Berat Badan Bayi Lahir}

Dari hasil penelitian yang dilakukan bulan Agustus 2020, terhadap 36 responden, mayoritas responden mempunyai bayi dengan berat badan lahir 2500-4000 gram yaitu sebanyak 23responden (64\%), berat badan bayi lahir <2500 gram sebanyak 3 responden (8\%) dan berat badan bayilahir $>4000$ gram sebanyak 10 responden $(28 \%)$.

Dari hasil uji silang menunjukkan bahwa dari 36 responden, mayoritas responden memiliki bayi dengan berat badan 2500-4000 sebanyak 23 responden (64\%),yang terdiri dari ibu yang mengalami ruptur perineum sebanyak 22 responden(61\%) dan yang tidak mengalami ruptur perineum sebanyak 1 responden (3\%).

Berdasarkan hasil uji Chi-Squaredengan tingkat kepercayaan 95\% $(\alpha=0,05)$ hasil perhitungan menunjukkan nilai $\mathrm{p}(0,000)<\mathrm{p}$ value $(0,05)$ berarti Ha diterima dan Ho ditolak, dengan demikian ada hubungan antara berat badan bayi saat lahir dengan kejadian ruptur perineum pada ibu setelah persalinan.

Berat badan bayi lahir normal adalah antara 2500-4000 gram, didapatkan dari hasil penimbangan 24 jam pertama kelahiran. Berat badan bayi baru lahir dapat mempengaruhi proses persalinan kala II. Bayi besar adalah bayi dengan berat badan lahir lebih dari 4000 gram, semakin besar berat badan bayi yang dilahirkan akan meningkatkan risiko terjadinya ruptur perineum karena perineum tidak cukup kuat menahan regangan kepala bayi dengan berat badan bayi yang besar, sehingga pada proses kelahiran bayi dengan berat badan bayi lahir yang besar sering terjadi ruptur (Destiati, 2011).

Ibu bersalin primigravida yang melahirkan bayi dengan berat badan 2500-4000 gram 
Journal of Healthcare Technology and Medicine Vol. 6 No. 2 Oktober 2020

Universitas Ubudiyah Indonesia

e-ISSN : 2615-109X

memiliki risiko lebih tinggi terhadap kejadian ruptur perineum dibandingkan dengan bayi dengan berat badan lahir <2500 gram. Faktor perineum ibu yang kaku, kepala janin yang cepat melewati dasar panggul, dan cara meneran yang salah juga meningkatkan risiko kejadian ruptur perineum. Persalinan normal bisa mengakibatkan terjadinya kasus ruptur perineum pada ibu primipara maupun multipara. Lapisan mukosa dan kulit perineum pada seorang ibu primipara mudah terjadi ruptur yang bisa menimbulkan perdarahan pervaginam.

Hasil penelitian ini didukung oleh penelitian sebelumnya yang pernah dilakukan oleh Icha pada tahun 2017 dengan judul "Faktor-faktor yang berhubungan dengan kejadian Ruptur Perenium pada ibu bersalin di Bidan Praktek Swasta Desa Mekarsari Kabupaten Bogor" menunjukkan ada hubungan antara berat badan bayi lahir dengan kejadian ruptur perineum di Bidan Praktek Swasta Desa Mekarsari Kabupaten Bogor yang ditunjukkan dengan nilai ( $\mathrm{p}$ 0.028, OR 1.144).

Asumsi peneliti, adanya hubungan antara berat badan bayi lahir dengan kejadian ruptur perineum, dimana berat badan bayi >4000 gram menyebabkan ruptur perineum hal ini dikarenakan kepala bayi yang besar atau kepala yang lebih keras (pada postmaturitas) dapat menyebabkan distosia sehingga seringkali akan menyebabkan ruptur perineum. Semakin besar berat badan bayi yang dilahirkan akan meningkatkan risiko terjadinya ruptur perineum karena perineum tidak cukup kuat menahan regangan kepala bayi dengan berat badan bayi yang besar, sehingga pada proses kelahiran bayi dengan berat badan bayi lahir yang besar sering terjadi ruptur. Begitu pula dengan berat badan bayi 2500-4000gram juga dapat mengalami ruptur perineum yaitu lebih dominan dengan berat badan 3500 gram, walaupun berat badan bayi dalam kategori normal tetapi ibu mengalami ruptur perineum, hal ini disebabkan karena resiko trauma partus melalui vagina seperti distosia bahu dan kerusakan jaringan lunak pada ibu.

\section{Paritas}

Dari hasil penelitian yang dilakukan bulan Agustus 2020, terhadap 36 responden,mayoritas responden merupakan multipara yaitu sebanyak 27 responden (75\%), primipara sebanyak 6 responden (17\%) dan grandemultipara sebanyak 3 responden (8\%). 
Journal of Healthcare Technology and Medicine Vol. 6 No. 2 Oktober 2020

Universitas Ubudiyah Indonesia

e-ISSN : 2615-109X

Berdasarkan uji silang diatas menunjukkan bahwa dari 36 responden, mayoritas responden multipara yaitu sebanyak 27 responden (75\%),yang terdiri dari ibu yang mengalami ruptur perineum sebanyak 21 responden (58\%) dan yang tidak mengalami ruptur perineum sebanyak 6 responden $(16 \%)$.

Dari hasil uji Chi-Square dengan tingkat kepercayaan 95\% $(\alpha=0,05)$ hasil perhitungan menunjukkan nilai $\mathrm{p}(0,377)>\mathrm{p}$ value $(0,05)$ berarti Ho diterima dan Ha ditolak, dengan demikian tidak ada hubungan antara paritas dengan kejadian ruptur perineum pada ibu setelah persalinan.

Paritas adalah jumlah anak yang pernah dilahirkan ibu baik lahir hidup maupun meninggal. Paritas ibu diklasifikasikan menjadi primipara (1 anak), multipara(2-4 anak), dan grandemultipara ( $>5$ anak). Paritas mempunyai pengaruh terhadap robekan perineum sesuai dengan teori bahwa pada ibu dengan paritas satu atau ibu primipara memiliki resiko lebih besar untuk mengalami robekan perineum daripada ibu dengan paritas lebih dari satu. Dikarenakan jalan lahir yang belum pernah dilalui oleh kepala bayi sehingga otot-otot perineum belum merenggang, partus presipitatus, mengejan terlalu kuat, edema dan kerapuhan pada perineum, serta persalinan dengan tindakan. Apabila dilihat dari faktor risikonya, ibu bersalin primipara memiliki risiko mengalami ruptur perineum lebih tinggi dibandingkan dengan ibu bersalin multipara, tergantung bagaimana penolong melakukan pertolongan persalinan dan asuhan sayang ibu pada saat proses persalinan (Yurniati, 2016).

Hasil penelitian ini tidak sejalan dengan penelitian sebelumnya yang pernah dilakukan oleh Ariany pada tahun 2018 "Faktor-faktor yang berhubungan dengan kejadian Ruptur perenium di Rumah Sakit Muhammadiyah Palembang" menunjukkan ada hubungan antara paritas dengan kejadian ruptur perineum di Rumah Sakit Muhammadiyah Palembang yang ditunjukkan dengan nilai p 0,006.

Asumsi peneliti tidak ada hubungan paritas dengan kejadian ruptur perineum hal ini disebabkan karena tidak selalu ibu dengan paritas sedikit (primipara) mengalami ruptur perineum dan paritas banyak (multipara dan grande multipara) tidak mengalami ruptur perineum. Hal ini bisa terjadi karena setiap ibu mempunyai tingkat elastisitas perineum yang berbeda - beda. Semakin elastis perineum maka kemungkinan tidak akan terjadi ruptur perineum dan juga sebagian karena berat badan bayi baru lahir, kerapuhan perineum, asuhan sayang ibu yang kurang baik sehingga proses persalinan kurang terkendali seperti ibu kelelahan, mengejan sebelum waktunya sehingga partus menjadi macet / lambat. 
Journal of Healthcare Technology and Medicine Vol. 6 No. 2 Oktober 2020

Universitas Ubudiyah Indonesia

e-ISSN : 2615-109X

\section{Jarak Kelahiran}

Dari hasil penelitian yang dilakukan bulan Agustus 2020, terhadap 36 responden,mayoritas responden memiliki jarak kelahiran $\geq 2$ tahun yaitu sebanyak 28 responden $(77 \%)$, anak pertama sebanyak 6 responden $(17 \%)$ dan $<2$ tahun sebanyak 2 responden $(6 \%)$.

Berdasarkan tabel diatas menunjukkan bahwa dari 36 responden, mayoritas responden mempunyai jarak kehamilan $\geq 2$ tahun yaitu sebanyak 28 responden (77\%),yang terdiri dari ibu yang mengalami ruptur perineum sebanyak 21 responden (58\%) dan yang tidak mengalami ruptur perineum sebanyak 7 responden (19\%).

Dari hasil uji Chi-Squaredengan tingkat kepercayaan 95\% $(\alpha=0,05)$ hasil perhitungan menunjukkan nilai p $(0,289)>$ p value $(0,05)$ berarti Ho diterima dan Ha ditolak, dengan demikian tidak ada hubungan antara jarak kehamilan dengan kejadian ruptur perineum pada ibu setelah persalinan.

Jarak kelahiran adalah rentang waktu antara kelahiran anak sekarang dengan kelahiran anak sebelumnya. Jarak kelahiran kurang dari dua tahun tergolong resiko tinggi karena dapat menimbulkan komplikasi pada persalinan (Rochmayanti, 2019).

Jarak anak yang ideal untuk menjaga kesehatan ibu dan anak adalah 2-5 tahun. Jarak yang ideal tersebut akan memberikan kesempatan kepada anak untuk tumbuh dan berkembang dengan lingkungan dan gizi yang optimal. Pengaturan jarak kehamilan yang ideal juga akan berdampak terhadap kesehatan ibu. Kesehatan reproduksi ibu akan mengalami pemulihan yang optimal jikajarakkehamilantidakteraludekat (Irawati, 2017).

Hasil penelitian ini tidak sejalan dengan penelitian sebelumnya yang pernah dilakukan oleh Sigalinging pada tahun 2017 dengan judul "Faktor-faktor yang berhubungan dengan terjadinya ruptur perineum pada ibu bersalin Di RSU Imelda Pekerja Indonesia Medan" menunjukkan adanya hubungan antara jarak kelahiran dengan kejadian ruptur perineum di RSU Imelda Pekerja Indonesia Medan yang ditunjukkan nilai ( $\mathrm{p}=0,043)$.

Asumsi peneliti tidak ada hubungan antara jarak kelahiran dengan kejadian ruptur perineum. Hal ini disebabkan karena mayoritas ibu yang mengalami rupture perineum yaitu ibu yang memiliki jarak kelahiran $\geq 2$ tahun dimana sistem reproduksi dan jalan lahir ibu telah mengalami proses pemulihan yang optimal. Akan tetapi ruptur perineum yang terjadi pada ibu yang memiliki jarak $\geq 2$ tahun ini dapat disebabkan oleh beberapa faktor diantaranya posisi 
Journal of Healthcare Technology and Medicine Vol. 6 No. 2 Oktober 2020

Universitas Ubudiyah Indonesia

e-ISSN : 2615-109X

meneran, cara memimpin mengejan dan ketrampilan menahan perineum pada saat ekspulsi kepala.

\section{KESIMPULAN}

Berdasarkan hasil penelitian dan pembahasan yang telah dijelaskan pada bab-bab sebelumnya, kesimpulan yang dapat ditarik dari penelitian ini adalah, Ada hubungan antara berat badan bayi lahir dengan kejadian ruptur perenium (nilai p 0,000), Tidak ada hubungan antara paritas dengan kejadian ruptur perenium (nilai p 0,377), dan Tidak ada hubungan antara jarak kelahiran dengan kejadian ruptur perenium (nilai p 0,289).

\section{SARAN}

Diharapkan kepada BPM Hj. Rosdiana, S.SiT Kecamatan Jeunib Kabupaten Bireuen untuk dapat meningkatkan pelayanan kesehatan, bidan juga diharapkan dapat bekerja sama dengan ibu dalam proses persalinan dan lebih memperhatikan faktor-faktor risiko yang dapat mempengaruhi kejadian ruptur perineuem sehingga kejadian ruptur perineum dapat dicegah.

\section{DAFTAR PUSTAKA}

Anggraini (2018). Hubungan Berat Badan Bayi Lahir Dengan Robekan Perineum Pada 92 Persalinan Fisiol.http://journal.unusa.ac.id.

Ariani (2018).Analisis Faktor - Faktor Yang Berhubungan Dengan Kejadian Ruptur perineum Spontan Pada Persalinan Normal. www//http.jurnal.stikes-aisyiyahpalembang.ac.id.

Iman, M (2016). Panduan Penyusunan Karya Tulis Ilmiah Bidan Kesehatan. Cita Pustaka : Medan

. (2015). Panduan Penyusunan Karya Tulis Ilmiah Bidan Kesehatan. Cita

Pustaka : Medan

(2014). Panduan Penyusunan Karya Tulis Ilmiah Bidan Kesehatan. Cita Pustaka : Medan

Irawati (2017). Faktor Yang Berhubungan Dengan Ruptur Perineum di Pukesmas Puri Kabupaten Mojokerto. http://index.php/publikasi_stikes_majapahit.

Kemkes, RI (2017). Profil kesehatan Indonesia. https://www.kemkes.go.id

Mutmainnah (2017). Asuhan Persalinan Normal Dan Bayi Baru Lahir. Andi offset. Yogyakarta

Pemiliana (2019). Faktor-Faktor Yang Berhubungan Dengan Ruptur Perineum Pada Persalinan Normal di Klinik Niar Medan Tahun 2018.http://jurnal.fkmumi.ac.id.

Puspitasari (2018). Asuhan kebidanan 2. Trans info media, Jakarta

Rochmayanti (2019). Pijat Perenium Selama Masa Kehamilan Terhadap Kejadian Ruptur Perineum. Jakad media. Surabaya 
Journal of Healthcare Technology and Medicine Vol. 6 No. 2 Oktober 2020

Universitas Ubudiyah Indonesia

e-ISSN : 2615-109X

Rufaida (2019). Asuhan Kebidanan Persalinan Dan Bayi Baru Lahir. Budi utama. Yogyakarta

Setyorini (2013). Belajar Tentang Persalinan. Graham ilmu. Jakarta

Sigalingging (2017). Faktor Yang Berhubungan Dengan Terjadinya Rupture Perineum Pada Ibu Bersalin Di RSU Imelda Pekerja Indonesia Medan. www//http.ejournal.helvetia.ac.id.

Solekhah (2017). Hubungan Berat Badan Bayi Baru Lahir Dengan Kejadian Ruptur Perineum Pada Persalinan Normal Primipara Di Pukesmas Tegalrejo. www//http.jurnalkesehatan.co.id.

Sulisdian (2019). BukuAjar Asuhan Kebidanan Persalinan dan Bayi Baru Lahir. Oase group. Jawa tengah

Sumaryani (2015). Hubungan Antara Paritas Dengan Kejadian Ruptur Perineum Pada Persalinan Normal Di Klinik Utama Asri Medical Center Yogyakarta dan RSUD Panembahan Senopati Bantul. www//journal.ugm.ac.id

Wijayanti (2019). Hubungan Berat Badan Bayi Baru Lahir Dengan Kejadian Ruptur Perineum Persalinan Normal Pada Ibu Primigravida. www//journal.uns.ac.id.

Yurniati (2016). Hubungan Paritas Dengan Terjadinya Robekan Perineum Spontan Pada Persalinan Normal. www.neliti.com.

Yugistyowati (2015). Penyebab Terjadinya Ruptur Perineum pada Persalinan Normal di RSUD Muntilan Kabupaten Magelang. www//http.ejournal.almaata.ac.id.

Zakir (2013). Faktor Yang Berhubungan Dengan Tindakan Ekstraksi Vakum Pasa Persalinan. www//ejournal.poltekkes.com. 